Original Research

\title{
Ethnic Foods Diet Program Improve Self-efficacy and Diet Compliance Among Type 2 Diabetic Patients
}

\section{Eka Misbahatul Mar'ah Has, Amira Aulia, Tiyas Kusumaningrum and Ferry Efendi}

Faculty of Nursing Universitas Airlangga, Surabaya, Indonesia

\begin{abstract}
Introduction: A well-balanced diet is one of the four pillars of diabetes selfmanagement. Patient's culture strongly influences intake food. Diabetic dietary guidelines which fit with the patient's culture is expected to improve patient's selfefficacy and diet compliance. This study was aimed to analyze the effect of ethnic foods diet program in improving self-efficacy and diet compliance among Type-2 Diabetes Mellitus (T2DM) patients.
\end{abstract}

Methods: This was quasy experiment research with pre and post-test control design. The population was 112 T2DM patients from Sasak Tribes, West Nusa Tenggara. Samples were 36 respondents, divided into intervention (18) and control (18) groups. The independent variable was the ethnic food diet (EFD) program, while the dependent variables were patient's self-efficacy and diet compliance. Data were collected using self-efficacy questionnaire and a 24-hour dietary recall form. Data were then analyzed using Wilcoxon Signed Rank Test and Mann Whitney U Test. The result showed differences in self-efficacy between pre and post-test in the treatment group $(\mathrm{p}=0,001)$, but there were no differences in the control group.

Results: There were differences in diet compliance in the treatment group $(p=0,001)$, but there were no differences in the control group. There were differences between treatment and control groups on self-efficacy $(p=0,000)$ and diet compliance $(\mathrm{p}=0,000)$.

Conclusion: Ethnic foods diet program can improve self-efficacy and diet compliance among T2DM patients because more comfortable and easier to be applied. Nurses can apply ethnic foods diet program as an intervention to promote healthy diet for T2DM patients.

\section{ARTICLE HISTORY}

Received: December 12, 2019

Accepted: January 1, 2020

\section{KEYWORDS}

diet compliance; ethnic foods; self-efficacy; transcultural nursing; type 2 diabetes mellitus patients

\section{CONTACT}

Eka Misbahatul Mar'ah Has $\triangle$ eka.m.has@fkp.unair.ac.id $\equiv$ Faculty of Nursing Universitas Airlangga, Surabaya, Indonesia

Cite this as: Has, E. M. M., Aulia, A., Kusumaningrum, T., \& Efendi, F. (2019). Ethnic Foods Diet Program Improve Selfefficacy and Diet Compliance Among Type 2 Diabetic Patients. Jurnal Ners, 14(2), 155-160. doi:http://dx.doi.org/10.20473/jn.v14i2.16642

\section{INTRODUCTION}

Diabetes is the third leading cause of death in Indonesia. The prevalence of T2DM patients increase from $1.5 \%$ to $2.0 \%$ during 2013-2018(Ministry of Health Indonesia, 2018). Previous research explained that more than $50 \%$ patient with $\mathrm{T} 2 \mathrm{DM}$ did not comply with their $\operatorname{diet}(\mathrm{WHO}, 2003)$. A noncompliance can lead to health complications and increase healthcare expenditures(ODPHP, 2018). The T2DM patients need reinforcement through health education program, to encourage them to understand T2DM management, including dietary management, for appropriate care and better quality of life(Sami, Ansari, Butt, \& Hamid, 2017).

A well-balanced diet is one of the four pillars of diabetes self-management. International Diabetes Federation (IDF) published a dietary guidelines for T2DM patients, with the right schedule, amount, and type of food(Hu, 2011). PERKENI (Indonesian Endocrinology Association) also had arranged dietary guidelines for T2DM patients(PERKENI, 2015). But, everyone has their own culture, likewise in choosing and preparing their meals. Culture can be influenced by their social environment, such as tribal groups(Hiza, Casavale, Guenther, \& Davis, 2013). Patient's culture strongly influences intake food. By 
Table 1 The Level of Self-efficacy $(n=18)$

\begin{tabular}{|c|c|c|c|c|c|c|c|c|}
\hline \multirow{3}{*}{ Categories } & \multicolumn{4}{|c|}{ Treatment group } & \multicolumn{4}{|c|}{ Control group } \\
\hline & \multicolumn{2}{|c|}{ Pre Test } & \multicolumn{2}{|c|}{ Post Test } & \multicolumn{2}{|c|}{ Pre Test } & \multicolumn{2}{|c|}{ Post Test } \\
\hline & $\mathbf{n}$ & $\%$ & $\mathbf{n}$ & $\%$ & $\mathbf{n}$ & $\%$ & $\mathbf{n}$ & $\%$ \\
\hline Strong & 6 & 33.3 & 17 & 94.4 & 6 & 33.3 & 6 & 33.3 \\
\hline Weak & 12 & 66.7 & 1 & 5.6 & 12 & 66.7 & 12 & 66.7 \\
\hline Wilcoxon Signed Rank test & \multirow{2}{*}{\multicolumn{4}{|c|}{$\mathrm{p}=0.001$}} & \multicolumn{4}{|c|}{$\mathrm{p}=0.317$} \\
\hline Mann-Whitney U test & & & & & & & & \\
\hline
\end{tabular}

Table 2 Dietary Compliance $(\mathrm{n}=18)$

\begin{tabular}{|c|c|c|c|c|c|c|c|c|}
\hline \multirow[t]{3}{*}{ Categories } & \multicolumn{4}{|c|}{ Treatment group } & \multicolumn{4}{|c|}{ Control group } \\
\hline & \multicolumn{2}{|c|}{ Pre-test } & \multicolumn{2}{|c|}{ Post-test } & \multicolumn{2}{|c|}{ Pre-test } & \multicolumn{2}{|c|}{ Post-test } \\
\hline & $\mathbf{n}$ & $\%$ & $\mathbf{n}$ & $\%$ & $\mathbf{n}$ & $\%$ & $\mathbf{n}$ & $\%$ \\
\hline \multicolumn{9}{|l|}{ Calories } \\
\hline Compliance & 6 & 33.3 & 13 & 72.2 & 8 & 44.4 & 9 & 50 \\
\hline Incompliance & 12 & 66.7 & 5 & 27.8 & 10 & 55.6 & 9 & 50 \\
\hline \multicolumn{9}{|l|}{ Meal time } \\
\hline Compliance & 12 & 66.7 & 12 & 66.7 & 11 & 38.9 & 9 & 50 \\
\hline Incompliance & 6 & 33.3 & 6 & 33.3 & 7 & 61.1 & 9 & 50 \\
\hline \multicolumn{9}{|l|}{ The type of food consumed } \\
\hline Compliance & 13 & 72.2 & 17 & 94.4 & 14 & 77.8 & 14 & 77.8 \\
\hline Incompliance & 5 & 27.8 & 1 & 5.6 & 4 & 22.2 & 4 & 22.2 \\
\hline \multicolumn{9}{|l|}{ Dietary compliance } \\
\hline Compliance & 7 & 38.9 & 12 & 66.7 & 7 & 38.9 & 5 & 27.8 \\
\hline Incompliance & 11 & 61.1 & 6 & 33.3 & 11 & 61.1 & 13 & 72.2 \\
\hline Wilcoxon Signed Rank test & \multicolumn{4}{|c|}{$\mathrm{p}=0.025$} & \multicolumn{4}{|c|}{$\mathrm{p}=0.157$} \\
\hline Mann-Whitney U test & & & & & & & & \\
\hline
\end{tabular}

tailoring the patient's specific cultural foods, it is hoped that their compliance and adherence would increase. Thus, leading to improved glycemic values and reduced complications from T2DM(Ramsumeer, 2016). So that, dietary guidelines which are concerning with patient's culture were needed.

Sasak Tribes is one of a tribe in Indonesia who lived at Lombok Island, province of West Nusa Tenggara(Syarifaturrahman \& Hanafi, 2017). The ingredient of Sasak meals was vegetables (32.46\%), spices $(29.82 \%)$, sweeteners and confectionaries (10.53\%), legumes $(9.65 \%)$, root crops $(7.02 \%)$, cereals $(4.39 \%)$, fruits $(2.63 \%)$, oils $(1.75 \%)$, and others $(1.75 \%)$. The typical characters of most Sasak meals are spicy and tasty, which can increase appetite. Generally, its contain plain staple, main dish (vegetable, meat, or mixed), side dish, and condiment. Sambel (chili sauce) is a condiment that must be available for most people. Sasak Tribes also have a culture named begibung, which means eat together in a large plate(Sukenti, Hakim, Purwanto, \& Matthews, 2016). This culture cannot be avoided, so people with T2DM should manage their diet. There were no dietary guidelines for T2DM patients from Sasak Tribes.

According to Leininger's Transcultural Nursing Theory, culturally-based nursing care which is harmonious with an individual or group's cultural beliefs, practices, and values can enhances client's well-being(McFarland \& Wehbe-Alamah, 2018). Ethnic foods are defined as foods originating from the heritage and culture of an ethnic group who use their knowledge of local ingredients of plants and/or animal sources(Kwon, 2015a). Ethnic foods diet
(EFD) program based on Sasak Tribes culture were expected to improve T2DM patients' self-efficacy and diet compliance through dietary guidelines and regular meeting. By choosing the healthy meals based on their ethnic food, they were expected to be more comfortable and have higher self-efficacy level in complying with their dietary guidelines. Subsequently, they will have a controlled blood glucose level. This study aimed to analyze the effect of EFD program on the level of self-efficacy and diet compliance among T2DM patients.

\section{METHOD}

This was a quasi-experimental pretest-posttest with the control group design. There were two groups, one intervention group (EFD program) and one control group (standard dietary guidelines for T2DM on primary health care).

The population were patient with T2DM patients from Sasak Tribes (N=112). Samples were taken by using purposive sampling. Eligibility criteria included: 1) aged 40-60 years old; 2) living at home; 4) have no complication; 4) not on a current diet; 5) able to speak and write in Bahasa, and 6) a willingness to participate. While the exclusion criteria included: 1) patient with cognitive impairment; and 2) patient who referred to the hospital. Eventually, 36 patients completed the study. Divided into treatment group $(n=18)$ and control group $(n=18)$. Matching was conducted by using age, gender, and present diet compliance level.

The independent variable in this research was EFD program. EFD program is completing nutritional needs by consuming traditional food based on the 
cultural or ethnic background but still in term of the specific instructions of any illness dietary program. In this program, individual should consume T2DM diet by using any kind of food source that is still related to the traditional food in Sasak Tribe. Patients attend 2x60 minutes' health education about dietary guidelines for the T2DM patients, based on ethnic food in Sasak Tribes. Each patient has specific calorie needs per day. To calculate the number of calories needed by the patients, researcher collaborate with the nutritionist. Health education was conducted by using lecture and demonstration method, with booklet as a media. The dependent variables were patient's self-efficacy level and dietary compliance. A week after health education, the researcher has done the home visit and ask patients to complete selfefficacy questionnaire and A 24-hour dietary recall. These questionnaires took approximately 45-60 minutes to complete. Answers were immediately checked to ensure that the questionnaire was filled out. If missing value were found, the questionnaire was returned to the patient so he or she could fill in the missing item. A small gift was provided as an award.

General demographic data and disease characteristic that were collected included age, gender, education, employment, and duration having T2DM.

Self-efficacy was assessed by self-efficacy questionnaire with Likert Scale. Respondents response to 14 items on 3-point scale with the number referring to 1 = disagree, 2 = uncertain, $3=$ agree for favorable questions and vice versa for unfavorable questions. The highest score was 42 . A high score on a self-efficacy questionnaire corresponded to a strong self-efficacy.

A 24-hour dietary recall was used to assess the patient's dietary compliance. A 24-hour dietary recall (24HR) is a structured interview intended to capture detailed information about all foods and beverages consumed by the respondent in the past 24 hours, from midnight to midnight the previous day. This form filled within $7 \times 24$ hours at the same time for all respondents by an everyday home visit and interview by the researcher. After filling it completely, researcher reviews the calories, meal time, and the type of food consumed by T2DM patient. Compliance means their calories, meal time, and the type of food consumed already fit with their diet program that was given in a booklet as a guidance about T2DM.

An ethics committee from Universitas Airlangga approved this research (reference number 596KEPK). All respondents were given information about the study and written informed consent was obtained from those patients who agreed to participate. The respondents complete informed consent while undergoing routine checkup at Puskesmas Narmada, West Nusa Tenggara (primary health care center). The grouping determined by several aspects, such as age, gender and diet adherence. Researcher gave nutritional instruction to respondents as a guidance to prepare the meal themselves at home.
Descriptive statistics were used to summarize the characteristics of samples. Frequencies were reported for categorical variables, and the mean were reported for continuous variables. Data were analyzed by using Wilcoxon Signed Rank Test to see the difference between pre and post-test scores on each group. Then using Mann Whitney U Test to understand the difference between post-test scores on intervention and control group. We considered $p<0.05$ to be statistically significant.

\section{RESULTS}

The mean age of respondents in this study was 52.05 years old for treatment group, and 50.73 years old for the control group. Most participants in the treatment group were female (88.9\%), unemployed (44.4\%), had graduated from high school (44.4\%), and more than three years suffer from Type 2 Diabetes $(66.67 \%)$. Most participants in the control group were female (88.9\%), unemployed (61.1\%), had graduated from high school (50\%), and more than three years suffer from Type 2 Diabetes (66.2\%). Therefore, no homogenity test were applied to the sample.

Table 1 had shown that on pretest most of the respondents on both groups have weak self-efficacy regarding with diet for Type 2 Diabetes (66.75\%). Posttest score has been demonstrated that most of the respondents on treatment group already has strong self-efficacy (94.4\%), but most of respondents on the control group still has weak self-efficacy (66.75\%).

Statistical analysis by using Wilcoxon Signed Rank Test which compares respondent's level of selfefficacy between pre and post-test on each group had shown that there were significant differences in the treatment group $(\mathrm{p}=0.001)$, but no significant differences in the control group $(\mathrm{p}=0.317)$. Mann Whitney Test was used to compare the level of selfefficacy on post-test between control and treatment group. The result had shown $\mathrm{p}=0.000(\mathrm{p}<0.05)$ which means there was a significant difference in the level of self-efficacy between control and treatment group after EFD program.

Table 2 had shown the patient's dietary compliance by using a 24-hour dietary recall. Pretest result on treatment group showed most of the respondents already comply with the meal time $(66.7 \%)$ and the type of food consumed (72.2\%), but not comply with the amount of calories consumed $(66.7 \%)$. Pretest result in the control group showed the same characteristic but varies in percentages. Posttest result in the treatment group showed that most of the respondents comply with their calories intake $(72.2 \%)$, meal time $(66.7 \%)$, and the type of food consumed (94.4\%). While posttest result in control group showed, half of the respondents comply with the amount of calories consumed (50\%) and the meal time $(50 \%)$. Most of the respondents also comply with the type of food consumed (77.8\%).

It can also be concluded that on pretest most of the respondents on treatment group not comply diet 
program for the patient with Type 2 Diabetes $(61.1 \%)$, so did most of the respondents on the control group (61.1\%). After EFD program, most of the respondents on treatment group comply with their diet program (66.7\%). While most of the respondents on control group who didn't get EFD program still not comply with their diet program, moreover the percentage is increasing.

Statistical analysis by using Wilcoxon Signed Rank Test which compares respondent's dietary compliance between pre and post-test on each group had shown that there were significant differences in the treatment group $(\mathrm{p}=0.025)$, but no significant differences in the control group $(\mathrm{p}=0.157)$. Mann Whitney Test was used to compare the dietary compliance on post-test between control and treatment group. The result had shown $\mathrm{p}=0.000$ $(\mathrm{p}<0.05)$ which means there was a significant difference in dietary compliance between control and treatment group after EFD program.

\section{DISCUSSION}

Perceived self-efficacy is defined as people's beliefs about their capabilities to produce designated levels of performance that exercise influence over events that affect their lives(Bandura \& Wessels, 1997). Self-efficacy can induce motivation through efficacy expectations and determining commitment to follow T2DM care management. So, self-efficacy is very important in changing self-care behavior process, especially in nutritious behavior(Mohebi, Azadbakht, Feizi, Sharifirad, \& Kargar, 2013). In this research, perceived self-efficacy referred to the T2DM patients' belief in their capabilities to follow the diet program, to control their blood glucose level. On pretest, most of the respondents in both groups have weak self-efficacy. It is understandable because most of the respondents were women. Self-efficacy can be influenced by gender. A man was more optimistic than women(Zimmerman \& Martinez-Pons, 1990).

As many as six respondents on both groups indicate a strong self-efficacy on the pretest. Bandura stated that individuals acquire information about their self-efficacy from four sources, includes: 1) performance outcomes; 2) vicarious experience; 3) verbal persuasion, and 4) physiological feedback(Bandura \& Wessels, 1997). Mastery experiences are the most influential source of efficacy information. If one has performed well at a task previously, he or she is more likely to feel competent and play well at a similarly associated task(Bandura, 1977). Individuals with high levels of self-efficacy approach difficult tasks as challenges to master rather than as threats to be avoided(Williams \& Williams, 2010). Respondents with strong self-efficacy on pretest have had T2DM since more than three years ago. As long as dealing with T2DM and its treatments, ones will have more experience and lesson learned from their past experiences. They will be built better self-efficacy to face their health condition.
After EFD program, by seeing respondents score on post-test, can be evaluated that almost all of the respondents on the treatment group had a strong level of self-efficacy, only one respondent on a low level. Most of the respondents have a significant increase on magnitude dimension. It indicates EFD program can increase the level of self-efficacy in the treatment group. Ethnic food can be defined as an ethnic group's or a country's cuisine that is culturally and socially accepted by consumers outside of the respective ethnic group(Kwon, 2015a). EFD program is a form of health education about dietary guidelines for the patient with T2DM, which is arranged to fit with patient's culture and ethnic food, and also fulfil the amount of calories needed by each patient. According to Leininger's Transcultural Nursing Theory, nursing care that respects to patient's culture can optimise the well-being of the client(McFarland \& Wehbe-Alamah, 2018). The patient can gain more knowledge about Sasak's cuisine which is still fit with dietary guidelines. So that, the barrier to comply with T2DM diet can be, and they feel easy to deal with this disease management.

EFD program can increase T2DM patient's selfefficacy to comply with their diet management. Previous research also found that culturally based diabetes self-management education can significantly increase diabetes self-management knowledge(Weldon Grunden, 2016). Bandura stated that culture could influence self-efficacy through values, beliefs, in a self-regulatory process which is functioned as a source to assess self-efficacy and also as a consequence of belief on one's selfefficacy(Bandura \& Wessels, 1997). Leininger assumed nursing as a profession, contribute to the harmony of culture and health services along sick and healthy to people with various cultural backgrounds(McFarland \& Wehbe-Alamah, 2018). Regarding the transcultural nursing approach, EFD program has been adapted to Sasak Tribes cultural needs, which given as a help, support, facility, or as a creative professional intervention, to help patient adapt and negotiate with their own culture which is beneficial for their health. So that, it can facilitate and increase self-efficacy to run a diet program.

Posttest result had shown that there was a significant increase in patient's dietary compliance, especially in the amount of calories consumed per day. During EFD program, respondents not only get information about dietary guidelines for the T2DM patients, but also type, portion, and recipe of food from Sasak's cuisine which can be consumed. Respondents also get a booklet to help them remind and re-read the material while at home. Health education can positively influence the health behaviour of individuals and communities as well as the living and working conditions that affect their health(Tones, Robinson, \& Tilford, 2013). Dale said, by using media, such as booklet, the effectiveness of health education can be optimized(Davis \& Summers, 2015). 
Compliance also influenced by ethnicity or culture. Cultural differences were associated with the kind of food selected and the way in cooking it(Ettner et al., 2009). Diet for patients with Type 2 Diabetes is more manageable to comply when there is no cultural barrier(Ramsumeer, 2016). They were already familiar with the taste and the way to produce it. A healthy EFD program was lead to better dietary compliance and blood glucose level. The principle of EFD programs is maintaining the culture owned by respondents(Kwon, 2015b). So that, respondents do not need a change in many types of food they consumed, especially for Sasak's Tribe.

EFD program significantly increases the T2DM patients' dietary compliance. Educational interventions regarding dietary guidelines that are adapted to culture have a significant influence both on the stability of blood glucose levels and also increase knowledge and dietary compliance in the T2DM patients(Schäfer et al., 2014). Another previous research found that education on healthy eating with a special module, regarding patient's culture (such as fasting for Ramadhan, for moeslem) improved adherence to a healthy diet(Pratiwi et al., 2018). The best educational program for the T2DM patients is a program which meets patient's culture and contextual condition. It can help them to be more active and create strategies to deal with the barrier and stress. It also gives a positive impact on a patient's self-management. It can be seen on the research's result, the level of self-efficacy and dietary compliance of T2DM patients from Sasak's Tribes rise significantly after EFD program which is designed to meet Sasak's cuisine.

Limitation of the study includes the relatively small sample size of 36 T2DM patients, which may limit the power to generalize research's findings. Post-test measurement should have conducted more than once to do longitudinal analysis.

\section{CONCLUSION}

EFD program can increase T2DM patient's selfefficacy to comply with their diet management. Regarding the transcultural nursing approach, EFD program has been adapted to Sasak Tribes cultural needs, which given as a help, support, facility, or as a creative professional intervention, to help patient adapt and negotiate with their own culture which is beneficial for their health. So that, it can facilitate and increase self-efficacy to run a diet program.

EFD program significantly increases the T2DM patients' dietary compliance. Educational interventions regarding dietary guidelines that are adapted to culture have a significant influence both on the stability of blood glucose levels and also increase knowledge and dietary compliance in the T2DM patients(Schäfer et al., 2014). The best educational program for the T2DM patients is a program which meets patient's culture and contextual condition. It can help them to be more active and create strategies to deal with the barrier and stress. It also gives a positive impact on a patient's self-management. It can be seen on the research's result, the level of selfefficacy and dietary compliance of T2DM patients from Sasak's Tribes rise significantly after EFD program which is designed to meet Sasak's cuisine.

\section{REFERENCES}

Al-Kaabi, J., Al-Maskari, F., Saadi, H., Afandi, B., Parkar, H., \& Nagelkerke, N. (2008). Assessment of dietary practice among diabetic patients in the United Arab Emirates. The Review of Diabetic Studies: RDS, 5(2), 110.

Bandura, A. (1977). Self-efficacy: toward a unifying theory of behavioral change. Psychological Review, 84(2), 191.

Bandura, A. (2004). Health promotion by social cognitive means. Health Education and Behavior, 31(2), 143-164. https://doi.org/10.1177/1090198104263660

Bandura, A., \& Wessels, S. (1997). Self-efficacy. New York: W.H. Freeman \& Company.

Bandura A. (1993). Percieved Self-Efficacy in Cognitive Development and Functioning. Educational Psychologist, 28(2), 117-148.

Cecil, H., \& Pinkerton, S. D. (2006). Magnitude: an important dimension of self-efficacy. Journal of Applied Social Psychology, 30(6), 1243-1267. https://doi.org/https://doi.org/10.1111/j.15591816.2000.tb02519.x

Davis, B., \& Summers, M. (2015). Applying dale's cone of experience to increase learning and retention: a study of student learning in a foundational leadership course. QScience Proceedings (World Congress on Engineering Education 2014), 6, 1-7. https://doi.org/10.5339/qproc.2015.elc2014.6

Ettner, S. L., Cadwell, B. L., Russell, L. B., Brown, A., Karter, A. J., Safford, M., ... Thompson, T. J. (2009). Investing time in health: do socioeconomically disadvantaged patients spend more or less extra time on diabetes self-care? Health Economics, 18(6), 645-663.

Hiza, H. A. B., Casavale, K. O., Guenther, P. M., \& Davis, C. A. (2013). Diet quality of Americans differs by age, sex, race/ethnicity, income, and education level. Journal of the Academy of Nutrition and Dietetics, 113(2), 297-306.

Hu, F. B. (2011). Globalization of diabetes: the role of diet, lifestyle, and genes. Diabetes Care, 34(6), 1249-1257.

Kwon, D. Y. (2015a). What is ethnic food? Journal of Ethnic Foods, 2(1), 1. https://doi.org/10.1016/j.jef.2015.02.001

Kwon, D. Y. (2015b). Why ethnic foods? Journal of $\begin{array}{lll}\text { Ethnic } & \text { Foods, }\end{array}$ https://doi.org/10.1016/j.jef.2015.08.006

McFarland, M. R., \& Wehbe-Alamah, H. B. (2018). Leininger's Transcultural Nursing: Concepts, Theories, Research, \& Practice (Fourth edi). New York: McGraw-Hill Education.

Ministry of Health Indonesia. (2018). Basic Health 
Research (RISKESDAS) Indonesia 2018. Retrieved January 10, 2019, from http://www.depkes.go.id/resources/download/i nfo-terkini/hasil-riskesdas-2018.pdf

Mohebi, S., Azadbakht, L., Feizi, A., Sharifirad, G., \& Kargar, M. (2013). Review the key role of selfefficacy in diabetes care. Journal of Education and Health Promotion, 2(36), 1-21. https://doi.org/10.4103/2277-9531.115827

ODPHP. (2018). Injury and violence prevention data details. Retrieved September 13, 2018, from https://www.healthypeople.gov/node/3497/dat a-details

PERKENI. (2015). Konsensus pengelolaan dan pencegahan diabetes melitus tipe 2 di Indonesia 2015. PB. PERKENI. Jakarta: PB Perkeni.

Pratiwi, I. N., Pawanis, Z., Hidayati, L., Widyawati, I. Y., Sukartini, T., Bakar, A., \& Mariyanti, H. (2018). The role of a healthy-eating educational module during Ramadan in a community health centre. Journal of Diabetes Nursing, 22(2), 13-13.

Ramsumeer, S. (2016). A plan for the implementation and evaluation of diet education in type 2 diabetes. Walden University. Retrieved from https://scholarworks.waldenu.edu/cgi/viewcont ent.cgi?referer $=\&$ httpsredir $=1 \&$ article $=3023 \&$ co ntext=dissertations

Sami, W., Ansari, T., Butt, N. S., \& Hamid, M. R. A. (2017). Effect of diet on type 2 diabetes mellitus: a review. International Journal of Health Sciences, 11(2),

65-71. https://doi.org/10.1002/dmrr.2515

Schäfer, I., Pawels, M., Küver, C., Pohontsch, N. J., Scherer, M., van den Bussche, H., \& Kaduszkiewicz, H. (2014). Strategies for improving participation in diabetes education. A qualitative study. PLoS One, 9(4), e95035.

Sukenti, K., Hakim, L., Purwanto, Y., \& Matthews, P. J. (2016). Ethnobotanical study on local cuisine of the Sasak tribe in Lombok Island, Indonesia. Journal of Ethnic Foods, (189-200), 189-200. https://doi.org/10.1016/j.jef.2016.08.002

Syarifaturrahman, W. K., \& Hanafi, N. (2017). The inflection of sasak language in kuripan village. International Journal of Social Sciences and Humanities, 1(3), 155-181. https://doi.org/http://dx.doi.org/10.21744/ijssh .v1i3.69

Tones, K., Robinson, Y. K., \& Tilford, S. (2013). Health education: effectiveness and efficiency. Springer.

Waspadji, S. (2016). Komplikasi kronik diabetes: mekanisme terjadinya, diagnosis dan strategi pengelolaan. In S. Setiati, I. Alwi, A. W. Sudoyo, M. S. K, B. Setiyahadi, \& A. F. Syam (Eds.), Buku Ajar Ilmu Penyakit Dalam (Edisi enam, Vol. 3). Jakarta: Interna Publishing.

Weldon Grunden, L. (2016). Culturally-based diabetes self-management education and diabetes knowledge in the hispanic population. Walden University. Retrieved from http://scholarworks.waldenu.edu/dissertations

WHO. (2003). 2003 World Health Organization (WHO)/International Society of Hypertension (ISH) statement on management of hypertension. Journal of Hypertension, 21(11), 1983-1992. Retrieved from https://journals.lww.com/jhypertension/Abstrac t/2003/11000/2003_World_Health_Organization _WHO_International.2.aspx

Williams, T., \& Williams, K. (2010). Self-efficacy and performance in mathematics: Reciprocal determinism in 33 nations. Journal of Educational Psychology, 102(2), 453.

Zimmerman, B. J., \& Martinez-Pons, M. (1990). Student differences in self-regulated learning: Relating grade, sex, and giftedness to self-efficacy and strategy use. Journal of Educational Psychology, 82(1), 51 